\title{
Modulation of Cisplatin Sensitivity and Growth Rate of an Ovarian Carcinoma Cell Line by Bombesin and Tumor Necrosis Factor- $\alpha$
}

\author{
Seiji Isonishi, * Antti P. Jekunen, ${ }^{*}$ Doreen K. Hom, ${ }^{*}$ Alan Eastman, ' Peter S. Edelstein, \\ Franz B. Thiebaut, ${ }^{\star}$ Randolph D. Christen, ${ }^{\star}$ and Stephen B. Howell* \\ ${ }^{*}$ Department of Gynecologic Oncology, Jikei University School of Medicine, Tokyo, Japan; ${ }^{\ddagger}$ School of Medicine and the Cancer Center \\ and ${ }^{\S}$ Department of Surgical Oncology, University of California San Diego, La Jolla, California 92093; \\ and 'Department of Pharmacology, Dartmouth Medical School, Hanover, New Hampshire 03755
}

\begin{abstract}
A twofold change in the cisplatin (DDP) sensitivity of 2008 human ovarian carcinoma cells is sufficient to reduce tumor response in vivo. The DDP sensitivity of these cells can be enhanced by activation of the epidermal growth factor and protein kinase $C$ signal transduction pathways. We report here that two endogenous growth factors, bombesin and tumor necrosis factor alpha (TNF $\alpha$ ), enhanced DDP sensitivity by factors of $1.7 \pm 0.1$ (SD)-fold and $1.8 \pm 0.1$ (SD)-fold, respectively. Both agents also produced sensitization in an 11-fold DDP-resistant 2008 subline. Neither bombesin nor TNF $\alpha$ changed the accumulation of DDP, glutathione content, or glutathione-Stransferase activity in $\mathbf{2 0 0 8}$ cells. However, a 2-h exposure to both bombesin and TNF $\alpha$ was sufficient to increase 2008 cloning efficiency by up to $2.6 \pm 0.1$ (SD)-fold and $2.2 \pm 0.1$ (SD)fold, and it increased average colony size by $1.35 \pm 0.1$ (SD)fold and 1.55 \pm 0.1 (SD)-fold, respectively. Bombesin increased intracellular free calcium, and this was blocked by the bombesin receptor-specific antagonist SC196, demonstrating that 2008 cells have functional bombesin receptors. These results indicate that bombesin and TNF $\alpha$ can enhance sensitivity to DDP in both DDP sensitive and resistant variants of a human ovarian carcinoma and that both agents serve as growth factors for this tumor. (J. Clin. Invest. 1992. 90:1436-1442.) Key words: drug resistance • signal transduction pathway $\bullet$ intracellular calcium • chemotherapy • mitogenesis • growth factor
\end{abstract}

\section{Introduction}

Ligand binding to a variety of receptors triggers the rapid generation of inositol triphosphate and diacylglycerol leading to the activation of protein kinase $\mathrm{C}(\mathrm{PKC})^{1}(1)$. Bombesin, a tetra-

Address correspondence and reprint requests to Stephen B. Howell, M.D., Department of Medicine, 0812, University of California, San Diego, La Jolla, CA 92093.

Received for publication 28 November 1990 and in revised form 13 February 1992

1. Abbreviations used in this paper: $\left(\mathrm{Ca}^{2+}\right)_{\mathrm{i}}$, intracellular free calcium; DDP, cis-diamminedichloroplatinum(II); [ $\left.{ }^{3} \mathrm{H}\right] \mathrm{DEP}$, cis-dichloro( $\left[{ }^{3} \mathrm{H}\right]$-ethylenediamine)-platinum(II); EGF, epidermal growth factor; GST, glutathione-S-transferase; $\mathrm{mCB}$, monochlorobimane; PKC, protein kinase C; TNF $\alpha$, tumor necrosis factor-alpha; TPA, 12-O-tetradecanoylphorbol-13-acetate.

J. Clin. Invest.

(C) The American Society for Clinical Investigation, Inc.

$0021-9738 / 92 / 10 / 1436 / 07 \$ 2.00$

Volume 90, October 1992, 1436-1442 decapeptide originally isolated from frog skin (2), has been shown to act as a mitogen for Swiss 3T3 fibroblasts (3) and human small cell lung carcinomas (4). This peptide also has potent pharmacological effects on pancreatic cells (5) and elicits the release of other peptide hormones such as insulin. Since the administration of this hormone stimulates the release of other peptides, it is difficult to obtain evidence for a direct biological activity of bombesin. In Swiss 3T3 cells, high affinity receptors specific for this peptide have been demonstrated (6), and bombesin is able to directly activate $\operatorname{PKC~(7).~There~is~also~}$ indirect evidence that bombesin can activate PKC in human tumor cells based on its ability to generate inositol triphosphates and increase intracellular free calcium $\left[\left(\mathrm{Ca}^{2+}\right)_{i}\right](5,8)$.

Tumor necrosis factor- $\alpha$ (TNF $\alpha)$, secreted by macrophages (9), is a cytokine with a wide range of regulatory actions on immune responses, inflammation, cell growth, and differentiation (10). TNF $\alpha$ has been reported to enhance the cytotoxicity of cis-diamminedichloro-platinum(II) (DDP) in vitro to a human stomach adenocarcinoma (11) and a human ovarian carcinoma cell line (12). In contrast, TNF $\alpha$ does not demonstrate an actual synergistic effect when combined with DDP in a human bladder transitional cell carcinoma in vivo (13). Furthermore, when TNF $\alpha$ was administered for the treatment of intraperitoneal ovarian cancer xenografts, although it prolonged survival in tumor-bearing mice (10), it also promoted the establishment of multiple subperitoneal tumors. Like 12$O$-tetradecanoyl-phorbol-13-acetate (TPA), TNF $\alpha$ activates PKC in some cell types and this in turn may result in increased AP-1 activity and induction of AP-1-responsive genes (14). This is considered to be a key mechanism mediating at least some of the biological effects of TNF $\alpha$ mentioned above.

We have previously reported that TPA activation of PKC increased DDP sensitivity by a factor of 2.5 -fold in human ovarian carcinoma 2008 cells (15). Likewise, epidermal growth factor (EGF), another potent activator of PKC, enhances DDP sensitivity by 3.1 -fold in the same cell line (16). We report here that bombesin and TNF $\alpha$, two endogenous ligands whose receptors have the potential of activating PKC, are also potent modulators of DDP sensitivity in 2008 cells and, moreover, are both mitogenic for this tumor.

\section{Methods}

Materials. Bombesin was purchased from Sigma Chemical Co. (St. Louis, MO). TNF $\alpha$ was purchased from Sigma Chemical Co. and Knoll Pharmaceuticals (Whippany, NJ). DDP was obtained from the Drug Synthesis and Chemistry Branch, Division of Cancer Treatment, National Cancer Institute (Bethesda, MD). Monochlorobimane (mCB) was purchased from Molecular Probes, Inc. (Eugene, OR). A stock solution of $\mathrm{mCB}$ was prepared in ethanol $(20 \mathrm{mM})$ and was kept at $0-5^{\circ} \mathrm{C}$, protected from light. cis-Dichloro $\left(\left[{ }^{3} \mathrm{H}\right]\right.$-ethylenediamine $)$ - 
platinum(II) ([ $\left.\left.{ }^{3} \mathrm{H}\right] \mathrm{DEP}\right)$ (specific activity $\geq 16.4(\mathrm{mCi} / \mathrm{mmol})$, an analog of DDP that produces adducts at identical sites in DNA, was synthesized as previously reported (17).

Tumor cell lines. The human cell line 2008 was established from a patient with a serious cystadenocarcinoma of the ovary (18). A resistant subline, designated $2008 / \mathrm{Cl}^{*} 5$, was obtained by 13 monthly selections with $1 \mu \mathrm{M}$ DDP followed by chronic exposure to DDP increased stepwise to $5 \mu \mathrm{M}(19)$. The cells were grown on tissue culture dishes in a humidified incubator at $37^{\circ} \mathrm{C}$ in a $5 \% \mathrm{CO}_{2}$ atmosphere. They were maintained in medium consisting of RPMI 1640 supplemented with $5 \%$ heat inactivated fetal calf serum, $2 \mathrm{mM}$ glutamine, $100 \mathrm{U} / \mathrm{ml}$ penicillin, and $100 \mu \mathrm{g} / \mathrm{ml}$ streptomycin (Irvine Scientific, Santa Ana, CA).

Bombesin and TNF $\alpha$ treatment and colony assays. Colony-forming assays were used to assess the mitogenic and sensitization effects of each factor (20). Cells, trypsinized from monolayer culture, were adjusted to a concentration of 3,750 cells $/ 5 \mathrm{ml}$ in a tissue culture tube (Corning Glass Works, Corning Medical and Scientific, Corning, NY). $5 \mu \mathrm{l}$ of bombesin or TNF $\alpha$ stock solution was added to each tube to produce a final concentration of 300 or $2.4 \mathrm{nM}$, respectively. $10 \mu \mathrm{l}$ of DDP diluted from the stock solution was then added; control tubes received diluent alone. Tubes were incubated in humidified $5 \% \mathrm{CO}_{2}$ in air for $2 \mathrm{~h}$. Each tube was then centrifuged and the cells were resuspended in $15 \mathrm{ml}$ of complete medium devoid of drugs, and $5 \mathrm{ml}$ of suspended cells were plated on $60-\mathrm{mm}$ polystyrene tissue culture dishes (Corning Glass Works) in triplicate. Plates were incubated in humidified $5 \% \mathrm{CO}_{2}$ air, and after $14 \mathrm{~d}$ plates were fixed with methanol and stained with Giemsa. Colonies of $>60$ cells were counted macroscopically. For the measurement of colony size, the longest diameter of each colony was determined microscopically in $\mathbf{5 0}$ colonies. Cloning efficacy under control conditions was $8 \%$.

Cell growth rate. Cell suspensions were incubated in tissue culture tubes with either $300 \mathrm{nM}$ bombesin or $2.4 \mathrm{nM} \mathrm{TNF} \alpha$ for $2 \mathrm{~h}$ in humidified $5 \% \mathrm{CO}_{2}$ in air. Each tube was then centrifuged and the resuspended cells were seeded at low density in the absence of bombesin or TNF $\alpha$ (2 $\times 10^{4} /$ well) in 24-well plates (Corning Glass Works). Cells were harvested at various time points and counted by hemocytometer.

$\left[{ }^{3} \mathrm{H}\right] D E P$ accumulation. Subconfluent monolayers of 2008 cells were treated with $37^{\circ} \mathrm{C}$ RPMI 1640 medium containing $5 \mu \mathrm{Ci} / \mathrm{ml}$ [ ${ }^{3} \mathrm{H}$ ]DEP and $5 \mu \mathrm{M}$ cold DEP for $2 \mathrm{~h}$. The medium was then aspirated, and the cells were washed rapidly with $4^{\circ} \mathrm{C} \mathrm{PBS}$ four times. $1 \mathrm{ml}$ of $1 \mathrm{~N}$ $\mathrm{NaOH}$ was added and the cells were allowed to digest overnight. A 25- $\mu \mathrm{l}$ aliquot was used for determination of protein content by the method of Bradford (21); $800 \mu \mathrm{l}$ was used for liquid-scintillation counting.

GSH content and glutathione-S-transferase (GST) activity. GSH content was measured by adjusting cells to $10^{6} / \mathrm{ml}$ and staining them with $25 \mu \mathrm{M} \mathrm{mCB}$ in complete medium at room temperature for the indicated time; relative cellular fluorescence was then immediately measured on a flow cytometer (Cytofluorograph IIs; Ortho Diagnostic Systems Inc., Raritan, NJ) with excitation and emission settings of 385 and $480 \mathrm{~nm}$, respectively. Values were converted from log fluorescence to linear fluorescence intensity by application of the equation $x$ $=10^{[(y-20) / 60]}$ where $x$ is the relative linear fluorescent intensity and $y$ is the mean log channel number. Cells that were nonviable on the basis of forward and right-angle light scatter were excluded from analysis. The forward rate constant for the conjugation of $\mathrm{MCB}$ by GST is given by the equation $K_{\mathrm{f}}=$ initial rate/[ $\mathrm{mCB}$ ] [GSH]. Since the GSH content in the unstimulated and stimulated state turned out to be the same, and the $\mathrm{mCB}$ concentration was identical, the effects of bombesin and TNF $\alpha$ induction on $K_{\mathrm{f}}$ could be estimated from their effects on the initial slope of the conjugation curve.

DNA adduct formation. Confluent monolayers growing in complete RPMI in $150 \mathrm{~cm}^{2}$ culture flasks (Corning Glass Works) underwent a medium change and were then incubated at $37^{\circ} \mathrm{C}$ for $2 \mathrm{~h}$ with $10 \mu \mathrm{Ci} / \mathrm{ml}\left[{ }^{3} \mathrm{H}\right] \mathrm{DEP}$ concurrently with either $300 \mathrm{nM}$ bombesin or 2.4 $\mathrm{nM}$ TNF $\alpha$. Cells were harvested by trypsinization, washed twice with ice-cold PBS, and then resuspended in $0.8 \mathrm{ml}$ of $100 \mathrm{mM} \mathrm{NaCl}, 10 \mathrm{mM}$
Tris-Cl, $\mathrm{pH} 8.0 ; 25 \mathrm{mM}$ EDTA; $0.5 \%$ SDS; $0.1 \mathrm{mg} / \mathrm{ml}$ proteinase $\mathrm{K}$, and digested at $50^{\circ} \mathrm{C}$ for $18 \mathrm{~h}$ with shaking. This was followed by extraction with phenol/chloroform, and the DNA was redissolved in 10 $\mathrm{mM}$ Tris- $\mathrm{Cl} \mathrm{pH} \mathrm{8.0,1} \mathrm{mM} \mathrm{EDTA} \mathrm{containing} 0.1 \mathrm{mg} / \mathrm{ml} \mathrm{RNase} A$ and digested at $37^{\circ} \mathrm{C}$ for $3 \mathrm{~h}$. After another extraction with phenol/chloroform, the DNA was precipitated with $70 \%$ ethanol and stored at $-70^{\circ} \mathrm{C}$. The platinated DNA was digested to deoxyribonucleosides and specific DNA-bound adducts were separated by HPLC (22). The peak height of deoxycytosine measured at $254 \mathrm{~nm}$ during elution was converted to nanomoles by comparison with a standard curve. The level of DNA platination was then expressed as dpm associated with the intrastrand guanine-guanine adduct $/ \mathrm{nmol}$ deoxycytosine.

Cell cycle phase distribution. $1 \times 10^{6} \log$ phase cells were exposed to bombesin or TNF $\alpha$ for $2 \mathrm{~h}$ while growing as a monolayer, after which the medium was replaced. Cells were harvested by trypsinization at 24 , 48 , and $72 \mathrm{~h}$ after exposure, fixed with ice-cold $70 \%$ ethanol, and then resuspended at $10^{6}$ cells $/ \mathrm{ml}$ in PBS containing $50 \mu \mathrm{M}$ propidium iodide and $1,000 \mathrm{U} / \mathrm{ml} \mathrm{RNase} A$ and incubated for $30 \mathrm{~min}$ at $37^{\circ}$ before being analyzed on a flow cytometer (CytoFluorograph; Ortho Diagnostics Systems, Inc.). The fraction of cells in each phase was determined using Multicycle Cell Cycle Software (Phoenix Flow Systems, San Diego, CA).

$\left(\mathrm{Ca}^{2+}\right)_{i}$ release. Cells were loaded over $30 \mathrm{~min}$ with $5 \mu \mathrm{M}$ of the fluorescent $\left(\mathrm{Ca}^{2+}\right)_{i}$ probe FURA2/AM (Calbiochem, San Diego, CA) in $\mathrm{NaCl}$ Ringer's solution maintained at $37^{\circ} \mathrm{C}$ and $\mathrm{pH} 7.4$ by aeration using a $95 \% \mathrm{O}_{2} 5 \% \mathrm{CO}_{2}$ gas mixture. Loaded cells were then placed onto a glass coverslip that had previously been coated with $5 \mathrm{mg} / \mathrm{ml}$ poly-L-lysine (Sigma Chemical Co.). The coverslip was then briefly rinsed in $\mathrm{NaCl}$, removing any remaining extracellular dye but leaving a number of cells attached to the poly-L-lysine coating, and then was attached with high vacuum grease to a donut-shaped glass tube, creating a chamber in which the cell-coated coverslip served as the floor. The glass-tubing wall of the chamber circulated heated water, and thus the $\mathrm{NaCl}$ added to the chamber to bathe the cells, again aerated to $\mathrm{pH}$ 7.4 , was maintained at $37^{\circ} \mathrm{C}$. This chamber was placed on an inverted microscope (Nikon Diaphot; Nikon Corp., Melville, NY), which was fiberoptically connected to a spectrofluorometer (SPEX AR-CM DM3000; SPEX Industries Inc., Edison, NJ). For each experiment, a small group (5-10) of loaded cells was selected and alternately excited at $340 \mathrm{~nm}$ and $380 \mathrm{~nm}$ while fluorescent emissions were measured at $505 \mathrm{~nm}$. Initially, emissions were measured while the cells were being bathed in $\mathrm{NaCl}$. After $60-120 \mathrm{~s}, 300 \mathrm{nM}$ bombesin was added to the bath and scanning continued. Approximately 2 min later, $25 \mu \mathrm{M}$ of the calcium ionophore ionomycin (Sigma Chemical Co.) was added to the solution, followed in $\sim 60 \mathrm{~s}$ by the addition of $60-120 \mathrm{mM}$ of the calcium-chelating agent, EGTA (Sigma Chemical Co.). These last two additions were necessary for calibration of the FURA dye emissions to calculate $\left(\mathrm{Ca}^{2+}\right)_{\mathrm{i}}$ levels using the Grynkiewicz Equation (23). Emission intensities from 2008 cells that were not loaded with the fluorescent probe were similarly recorded, and these measured "autofluorescent" emissions were subtracted from measured intensities emitted by the loaded cells before calculating $\left(\mathrm{Ca}^{2+}\right)_{i}$ concentrations.

In a second set of experiments, identically loaded 2008 cells were exposed for $15 \mathrm{~min}$ to $30 \mu \mathrm{M}$ SC196, Ac-Met-Tyr-Pro-Arg-Gly-AsnHis-Trp-Ala-Val-Gly-His-Leu $\psi$ Leu- $\mathrm{NH}_{2}$ (a generous gift of Drs. John Steward and Lajos Gere, UCHSC, Denver, CO), a highly specific bombesin-receptor antagonist (24), before excitation. Initially, cells were excited while being bathed in $\mathrm{NaCl}$ plus $30 \mu \mathrm{M} \mathrm{SC196}$. Bombesin 300 $\mathrm{nM}$ was added to the physiologic solution after $2 \mathrm{~min}$. The ratio of 340:380 nm emission intensities was calculated to determine whether changes in $\left(\mathrm{Ca}^{2+}\right)_{i}$ concentrations occurred in response to the addition of bombesin.

\section{Results}

Effect of bombesin and TNF $\alpha$ on DDP sensitivity. Fig. 1 (left) shows that when 2008 cells were exposed concurrently for $2 \mathrm{~h}$ 


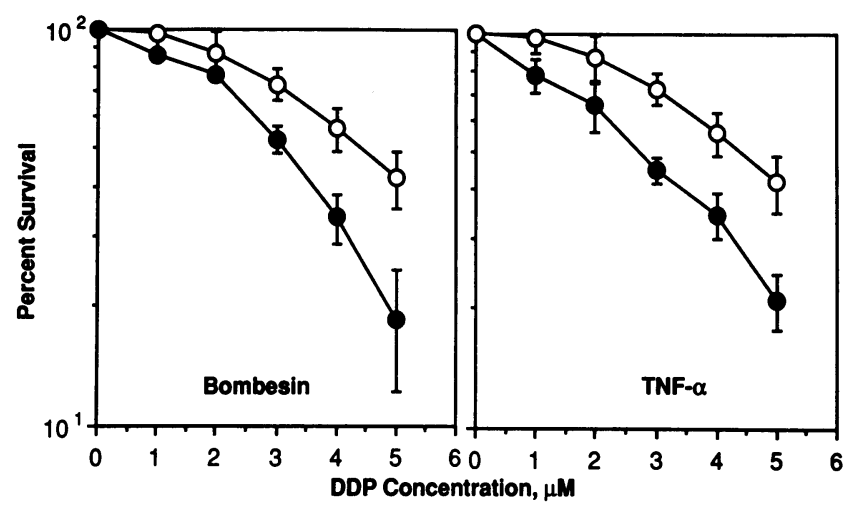

Figure 1. Sensitivity of 2008 cells to DDP in the presence (closed circles) or absence (open circles) of growth factors. Cells were treated as follows: (left ) 2-h exposure to DDP concurrently with $300 \mathrm{nM}$ bombesin; (right) 2 h exposure to DDP concurrently with $2.4 \mathrm{nM}$ TNF $\alpha$. DDP cytotoxicity was determined by clonogenic assay. Data points represent mean values of three experiments performed with triplicate cultures; bars represent SD.

to $300 \mathrm{nM}$ bombesin and DDP, and then both agents were removed from the cultures during the period of colony formation, bombesin increased DDP sensitivity. The $\mathrm{IC}_{50}$ in the absence of bombesin was $4.50 \pm 1.0 \mu \mathrm{M}(\mathrm{SD})$, whereas in the presence of bombesin it was $2.67 \pm 0.21 \mu \mathrm{M}$ (SD). Thus, bombesin produced a 1.7 -fold increase in sensitivity $(n=3 ; P<0.01)$. Likewise, the Fig. 1 (right) shows that when 2008 cells were exposed concurrently for $2 \mathrm{~h}$ to $2.4 \mathrm{nM} \mathrm{TNF} \alpha$ and DDP, $\mathrm{TNF} \alpha$ increased DDP sensitivity. The $\mathrm{IC}_{50}$ in the presence of TNF $\alpha$ was $2.57 \pm 0.29 \mu \mathrm{M}$ (SD). Thus, TNF $\alpha$ produced a 1.8fold increase in sensitivity $(n=3 ; P<0.01)$. Both bombesin and TNF $\alpha$ at concentrations even up to 10 and $120 \mu \mathrm{M}$ did not cause any toxicity by themselves; thus, the interaction between bombesin and TNF $\alpha$ and DDP was truly synergistic as defined by median effect analysis (25).

Enhancement of sensitivity in DDP-resistant cells. The $2008 / \mathrm{C13}$ *5 cell line is 11-fold resistant to DDP. Fig. 2 (left) shows that when these cells were exposed for $2 \mathrm{~h}$ concurrently to bombesin and DDP, the $\mathrm{IC}_{50}$ was reduced from 39.0 to 21.5 $\mu \mathrm{M}$. The $1.6 \pm 0.3$ (SD)-fold sensitization, quantitated by change in the slope of linear portion of these dose-response curves, was nearly identical to the 1.7 -fold sensitization observed in the DDP-sensitive 2008 cells $(n=3 ; P<0.01)$. Similarly, Fig. 2 (right) shows that when cells were exposed for $2 \mathrm{~h}$ concurrently to TNF $\alpha$ and DDP, the $\mathrm{IC}_{50}$ was reduced to 22.5 $\mu \mathrm{M}$. The $1.6 \pm 0.9$ (SD)-fold sensitization, quantitated by change in the slope of these curves, was likewise nearly identical to the 1.8-fold sensitization observed in the DDP-sensitive 2008 cells $(n=3 ; P<0.01)$. Thus we concluded that both bombesin and TNF $\alpha$ increased DDP sensitivity as effectively in DDP-resistant as in DDP-sensitive variants of 2008.

Effect of bombesin and TNF $\alpha$ on cellular accumulation of $\left[{ }^{3} H\right] D E P$. The 2008 cells were treated concurrently with $\left[{ }^{3} \mathrm{H}\right]$ DEP and either bombesin or TNF $\alpha$ for $2 \mathrm{~h}$. A vehicle control consisting of an appropriate dilution of saline was run concurrently. Neither the bombesin nor the TNF $\alpha$ produced any effect on cellular accumulation of $\left[{ }^{3} \mathrm{H}\right] \mathrm{DEP}$. Cells treated with saline contained $41.1 \pm 0.3$ (SD) $\mathrm{pmol} / \mathrm{mg}$ protein, whereas those treated with the bombesin contained $38.4 \pm 2.2$ (SD) $\mathrm{pmol} / \mathrm{mg}$ protein and those treated with TNF $\alpha$ con- tained $38.5 \pm 0.1(\mathrm{SD}) \mathrm{pmol} / \mathrm{mg}$ protein. Thus, bombesin and $\mathrm{TNF} \alpha$ altered DDP sensitivity by a mechanism that does not involve an increased amount of drug entering the cell.

Effect of bombesin and TNF $\alpha$ on cellular GSH content and the activity of GST. mCB reacts quantitatively with GSH via GST to form a fluorescent product readily quantitated by flow cytometry. 2008 cells were stained with $25 \mu \mathrm{M}$ mCB for various periods of time and relative fluorescence was determined immediately by flow cytometry. Maximum staining was obtained by $50 \mathrm{~min}$, and this staining time was used for comparison of GSH content. GSH content of bombesin-treated cells was $103 \pm 10 \%(\mathrm{SD} ; n=3)$ of that in the untreated cells; the relative GSH content of TNF $\alpha$-treated cells was $96.5 \pm 2 \%$ (SD; $n=3$ ). Thus, bombesin and TNF $\alpha$ did not alter GSH content significantly. Since there was no difference in GSH content, the initial rate of reaction between GSH and $\mathrm{mCB}$ can be used to estimate the rate constant for the GST-mediated reaction of $\mathrm{mCB}$ with $\mathrm{GSH}$, assuming that $\mathrm{mCB}$ has equal access to the GSH in both cell types. GST activity in the presence of bombesin was $96.7 \pm 8.3 \%$ (SD) of that in the untreated cells; in the case of TNF $\alpha$ it was $103.6 \pm 8.9 \%$ (SD). Thus, bombesin and TNF $\alpha$ did not produce a significant change in GST when activity was assayed in this manner.

Effect of bombesin and TNF $\alpha$ on platinum DNA adduct formation. Intrastrand DNA cross-link formation can be quantitated using [ $\left.{ }^{3} \mathrm{H}\right] \mathrm{DEP}$ as reported by Eastman (17). This technique specifically permits quantitation of the most abundant adduct, the guanine-guanine intrastrand cross-link. $\left[{ }^{3} \mathrm{H}\right] \mathrm{DEP}$ DNA adduct formation in bombesin or TNF $\alpha$-treated 2008 cells was $110.7 \pm 27.47$ (SD) and $128.33 \pm 15.14$ (SD) dpm/ nmol deoxycytosine, whereas it was $108.7 \pm 6.03$ (SD) in untreated control cells. Thus, despite increasing DDP sensitivity, bombesin and TNF $\alpha$ did not cause any significant increase in DNA intrastrand cross-link formation.

Dose-dependent effect of bombesin and TNF $\alpha$ on clonogenicity of 2008 cells. Fig. 3 shows the effect of a 2-h exposure to bombesin (top) and TNF $\alpha$ (bottom) on the subsequent cloning efficiency of 2008 cells. Bombesin increased the cloning effi-

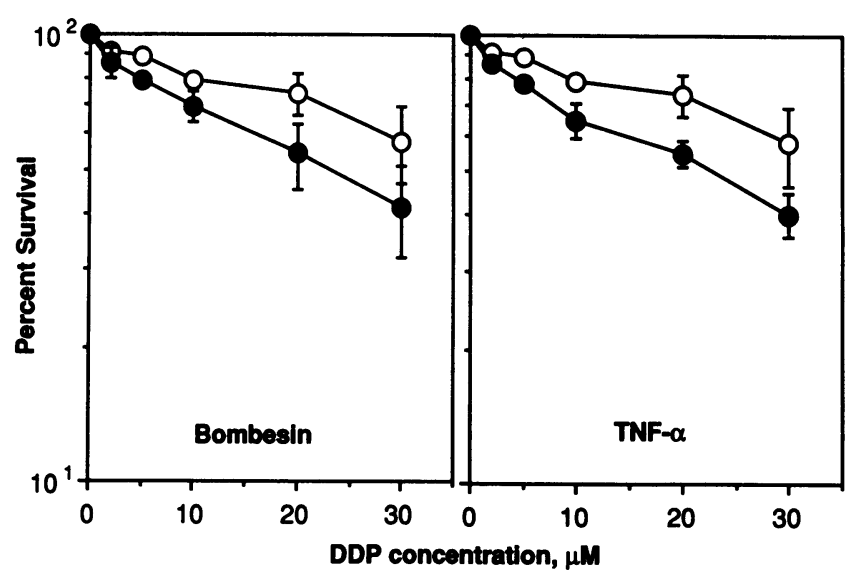

Figure 2. The effect of bombesin and TNF $\alpha$ on the DDP sensitivity of DDP-resistant cells. $\mathrm{C13} * 5$ cells were treated with various concentrations of DDP in the presence (closed circles) or absence (open circles) of $300 \mathrm{nM}$ bombesin (left) or $2.4 \mathrm{nM}$ TNF $\alpha$ (right) for $2 \mathrm{~h}$. DDP cytotoxicity was determined by clonogenic assay on plastic dishes. Data points are mean values of three experiments performed with triplicate cultures; bars represent SD. 


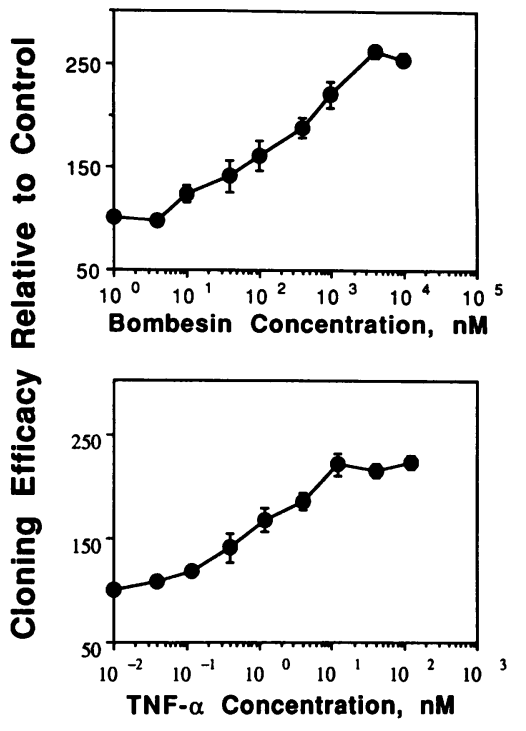

Figure 3. Dose-dependent effect of bombesin and TNF $\alpha$ on 2008 cloning efficiency. Cells were treated as follows: (top) 2-h drug exposure to bombesin at various concentrations from 10 $\mathrm{nM}$ to $10 \mu \mathrm{M}$; (bottom) 2-h drug exposure to TNF $\alpha$ at various concentrations from 0.12 to $120 \mathrm{nM}$. Data points represent the mean of two experiments performed with triplicate cultures; bars represent $\mathrm{SD}$ (where greater than symbol size).

cacy in a dose-dependent fashion with the maximum of $262 \pm 6 \%$ (SD) of control being attained at a concentration of 4 $\mu \mathrm{M}(n=2 ; P<0.01)$. Similarly, TNF $\alpha$ increased clonogenicity in a dose-dependent fashion, producing a maximum of $221 \pm 11 \%$ (SD) relative to control at a concentration of $12 \mathrm{nM}$ ( $n=2 ; P<0.01$ ), after which a plateau was observed. Thus both bombesin and TNF $\alpha$ enhanced the cloning efficacy of 2008 cells with the maximum effect of bombesin being greater than that of TNF $\alpha$.

Effect of bombesin and TNF $\alpha$ on colony-size distribution. Fig. 4 shows the colony-size distribution of control 2008 cells (top) or 2008 cells treated with either $300 \mathrm{nM}$ bombesin ( $m i d-$ dle) or $2.4 \mathrm{nM} \mathrm{TNF} \alpha$ (bottom) for $2 \mathrm{~h}$ and then washed before plating. In this experiment cells were cultured for $15 \mathrm{~d}$ after treatment with bombesin or TNF $\alpha$ to obtain larger colonies. Both bombesin and TNF $\alpha$ shifted the frequency histogram to the right. The average colony diameter in the control case was

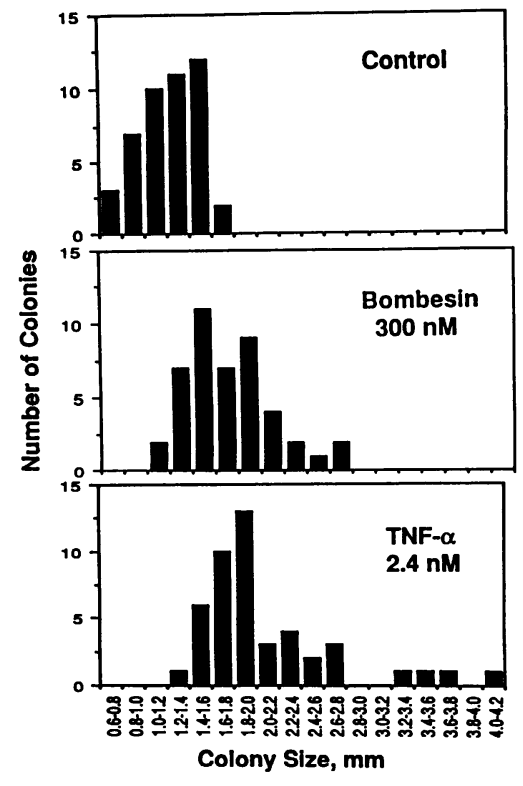

Figure 4. Colony-size distribution in the presence or absence of growth factors. Cells were treated as follows: (top) cells were cultured without any factors; (middle) 2-h drug exposure to $300 \mathrm{nM}$ bombesin alone; (bottom) 2-h drug exposure to 2.4 nM TNF $\alpha$ alone. Colony diameter was determined by a microscope fitted with a micrometer.

$1.20 \pm 0.26 \mathrm{~mm}$ (SD), whereas after treatment with bombesin it was $1.70 \pm 0.40 \mathrm{~mm}$ (SD), an increase of 1.42-fold ( $n=45 ; P$ $<0.01)$. Similarly, the mean colony size after treatment with TNF $\alpha$ was $2.01 \pm 0.55 \mathrm{~mm}$ (SD), an increase of 1.68 -fold ( $n$ $=45 ; P<0.01$ ).

It should be noted that both bombesin and TNF $\alpha$ increased the range of colony sizes. For the control cultures size ranged from 0.6 to $1.7 \mathrm{~mm}$, whereas it ranged from 1.0 to $2.85 \mathrm{~mm}$ after exposure to bombesin and from 1.3 to $4.0 \mathrm{~mm}$ after exposure to TNF $\alpha$. Thus the coefficient of variation in colony size after treatment with either bombesin or TNF $\alpha$ was larger than control.

Dose dependence of the effect of bombesin and TNF $\alpha$ on colony size. Table I shows that, like the effect on cloning efficiency, the effect of bombesin and TNF $\alpha$ on mean colony size was also concentration dependent. Despite the small size of the colonies in these experiments (cells were incubated for $10 \mathrm{~d}$ after drug treatment) compared with the data presented above, bombesin significantly increased the colony size at each dose level ( $n=20 ; P<0.01$ ), and the maximum colony size was observed at a bombesin concentration of $400 \mathrm{nM}$. Similarly, TNF $\alpha$ significantly increased the colony size in each dose level ( $n=20 ; P<0.01$ ), and the maximum colony size was observed at a TNF $\alpha$ concentration of $4.0 \mathrm{nM}$. The maximum increase in mean colony size with bombesin was $1.36 \pm 0.07$ (SD)-fold, whereas it was somewhat larger at $2.04 \pm 0.10$ (SD)fold with TNF $\alpha(n=20 ; P<0.01)$.

Effect of bombesin and TNF $\alpha$ on growth rate of 2008 cells. An increase in apparent cloning efficiency and mean colony size is most readily explained by an increase in cell-doubling rate. Bombesin $300 \mathrm{nM}$ and TNF $\alpha 2.4 \mathrm{nM}$ increased the exponential growth-rate constant of 2008 cells by a factor of $1.09 \pm 0.01$ (SD) and $1.15 \pm 0.01$ (SD), $(P<0.01, t$ test $)$, respectively. Although bombesin and TNF $\alpha$ had equivalent mitogenic effects on 2008 cells with regard to growth rate at the concentrations used, neither agent altered the level of the plateau phase of growth (data not shown).

A further demonstration of the mitogenic effect of bombesin and TNF $\alpha$ is shown in Fig. 5. Cells were treated with a single 2-h exposure to $300 \mathrm{nM}$ bombesin or $2.4 \mathrm{nM}$ TNF $\alpha$,

Table I. Effect of Bombesin and Tumor Necrosis Factor- $\alpha$ on Average Colony Size

\begin{tabular}{cccc}
\hline $\begin{array}{c}\text { Growth } \\
\text { factor }\end{array}$ & Concentration & Colony size & $\begin{array}{c}\text { Fold } \\
\text { increase* }\end{array}$ \\
\hline \multirow{3}{*}{ Bombesin } & $n M$ & $M M$ & \\
& 0 & $0.76 \pm 0.05$ & 1.00 \\
& 100 & $0.84 \pm 0.04^{\ddagger}$ & $1.10 \pm 0.06$ \\
& 400 & $1.04 \pm 0.05^{\ddagger}$ & $1.36 \pm 0.07$ \\
TNF $\alpha$ & 4000 & $0.90 \pm 0.05^{\ddagger}$ & $1.18 \pm 0.07$ \\
& 0 & $0.76 \pm 0.05$ & 1.00 \\
& 0.4 & $1.01 \pm 0.06^{\ddagger}$ & $1.32 \pm 0.07$ \\
& 4.0 & $1.55 \pm 0.08^{\ddagger}$ & $2.04 \pm 0.10$ \\
& 40.0 & $1.55 \pm 0.04^{\ddagger 5}$ & $2.03 \pm 0.05$ \\
\hline
\end{tabular}

\footnotetext{
* Mean \pm SD.

${ }^{\ddagger} P<0.01$ relative to control.

${ }^{\S} P<0.01$ relative to $400 \mathrm{mM}$ bombesin.
} 


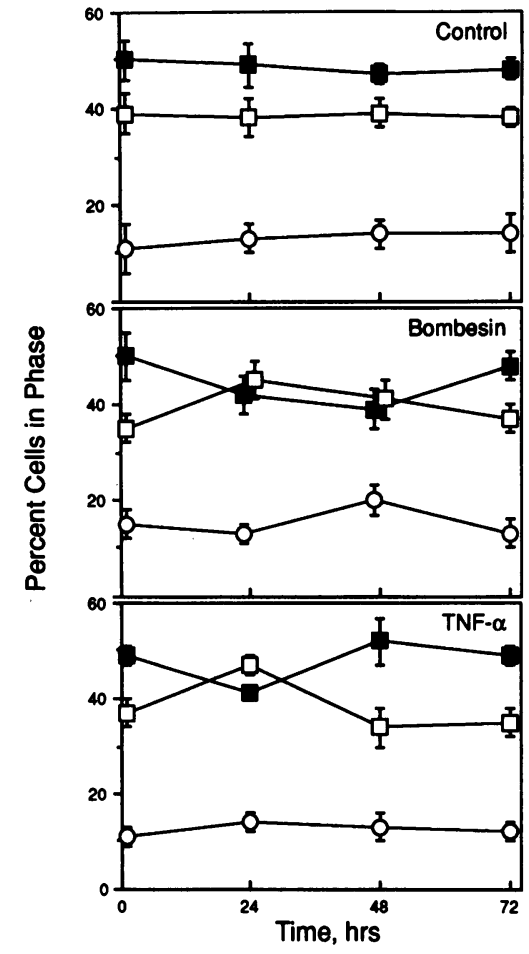

Figure 5. Changes in cell cycle phase distribution induced by bombesin and TNF $\alpha$. Log phase cultures of 2008 cells were treated for $2 \mathrm{~h}$ with either 300 $\mathrm{nM}$ bombesin (middle) or $2.4 \mathrm{nM}$ TNF $\alpha$ (bottom). Top panel shows the cell cycle distribution without any treatment. At the indicated times, cell cycle phase distribution was determined by flow cytometry. Data points present the mean $\pm S D$ of three experiments. $\square, G_{1}$ phase cells; $\square, S$ phase cells; $\circ, G_{2}$ phase cells.

washed, and the cell cycle phase distribution determined by flow cytometry at 24-h intervals for $3 \mathrm{~d}$. Both agents produced an increase in the fraction of cells in $\mathrm{S}$ phase at the expense of $\mathrm{G}_{1}$ phase by $24 \mathrm{~h}(P<0.05$ for both $)$. After exposure to TNF $\alpha$ this cell-cycle phase perturbation returned to normal by $48 \mathrm{~h}$; the response was more prolonged with bombesin, requiring 72 $\mathrm{h}$ to return to baseline. Control cells, which were plated at the same density as bombesin- and TNF $\alpha$-treated cells, showed no perturbation of the cell cycle phase distribution during the 72-h observation period. This indicates that during the experiment the cells remained in log phase growth. These results indicate that the effect of a 2-h exposure to bombesin and TNF $\alpha$ on cloning efficiency and colony size can be accounted for by a direct mitogenic effect on cell proliferation.

$\left(\mathrm{Ca}^{2+}\right)_{i}$ release. To demonstrate the presence of functional bombesin-specific receptors on 2008 cells, the effect of bombesin on $\left(\mathrm{Ca}^{2+}\right)_{\mathrm{i}}$ was measured in the presence and absence of the bombesin-specific antagonist SC196. When grown in 5\% bovine calf serum, $300 \mathrm{nM}$ bombesin increased $\left(\mathrm{Ca}^{2+}\right)_{\mathrm{i}}$ in $8 \%$ of the cells, whereas when grown in $5 \%$ fetal calf serum, or when serum starved for $24 \mathrm{~h}$, bombesin increased $\left(\mathrm{Ca}^{2+}\right)_{\mathrm{i}}$ in 50 and $100 \%$ of 2008 cells, respectively. In cells grown in fetal calf serum and then serum starved for $24 \mathrm{~h}$, the basal $\left(\mathrm{Ca}^{2+}\right)_{i}$ varied between 63 and $284 \mathrm{nM}$. Bombesin increased $\left(\mathrm{Ca}^{2+}\right)_{\mathrm{i}}$ concentration by $1.13-1.68$-fold in $100 \%$ of 60 cells examined. A typical example of this response to $300 \mathrm{nM}$ bombesin is shown in Fig. 6, which also shows that the bombesin-specific antagonist SC196 completely blocked the ability of $300 \mathrm{nM}$ to elevate $\left(\mathrm{Ca}^{2+}\right)_{\mathrm{i}}$. This blockade was observed in $100 \%$ of the 60 cells examined.

Effect of cell density on DDP sensitivity. Fig. 7 shows that there is no difference between cells grown in different densities with respect to DDP sensitivity. In both cases $\mathrm{IC}_{50}$ for $1 \mathrm{~h}$ of DDP exposure was $1.5 \mu \mathrm{M}$. It is obvious that the confluency of

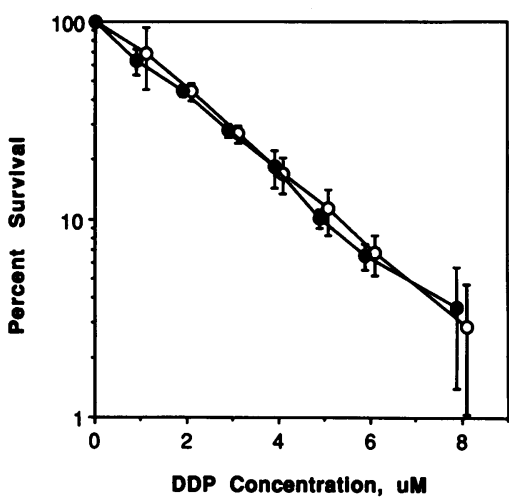

Figure 6. The effect of cell density on the DDP sensitivity of 2008 cells. Cells were treated $1 \mathrm{~h}$ with various concentrations of DDP in cell suspension from halfconfluent (open circle) and over-confluent (closed circle) parent cultures. DDP cytotoxicity was determined by clonogenic assay on plastic dishes. Data points are mean values of three experiments performed with triplicate cultures; bars represent $\mathrm{SD}$.

the starting parent culture has no effect on final DDP cell survival.

\section{Discussion}

The finding that bombesin induces activation of PKC (7) and the wide distribution of endogenous mammalian analogs of bombesin (26) suggest that this peptide may play an important role in controlling the phenotype of both normal and malignant cells. Such a role has already been established for TNF $\alpha$, which is also capable of activating PKC in some cell types (14).

The first major finding resulting from the studies reported here was that the signal transduction pathways activated by both bombesin and TNF $\alpha$ can modulate the sensitivity of the human ovarian carcinoma cell line 2008 to DDP, the most clinically important drug for the treatment of this malignancy. The effect was produced by exposure to growth factor for just 2 $h$, indicating that enhancement of sensitivity was the result of the triggering of a cascade of events initiated by ligand binding rather than a mechanism that required the continuous presence of exogenous ligand. Other investigators have also found that TNF $\alpha$ will modulate DDP sensitivity in a human ovarian carcinoma (12) and a gastric adenocarcinoma (11) cell line, but the ability of bombesin to enhance sensitivity to DDP has not been reported previously. Bombesin and TNF $\alpha$ thus join a rapidly growing list of receptor ligands and other signal transduction pathway activators that modulate DDP sensitivity in 2008 cells. We have previously reported that brief exposure to EGF (16), activation of the PKC pathway with TPA (15), or activation of the protein kinase A pathway with forskolin (27) all enhance DDP sensitivity to varying degrees. Although the magnitude of the modulation produced by all of these activators is relatively small (1.6-3.2-fold), levels of resistance as small as 2.5 -fold produce clearly reduced response to DDP treatment in vivo when the 2008 cells are grown as a xenograft (28). Irrespective of whether such modulation is clinically relevant, the ability of these factors to enhance sensitivity in the 2008 cells provides an additional approach to understanding the mechanism by which cells defend themselves against this chemotherapeutic agent.

The major mechanisms mediating resistance to DDP include impairment of drug uptake, elevated levels of GSH or metallothioneins, or enhanced DNA repair (for review see ref- 

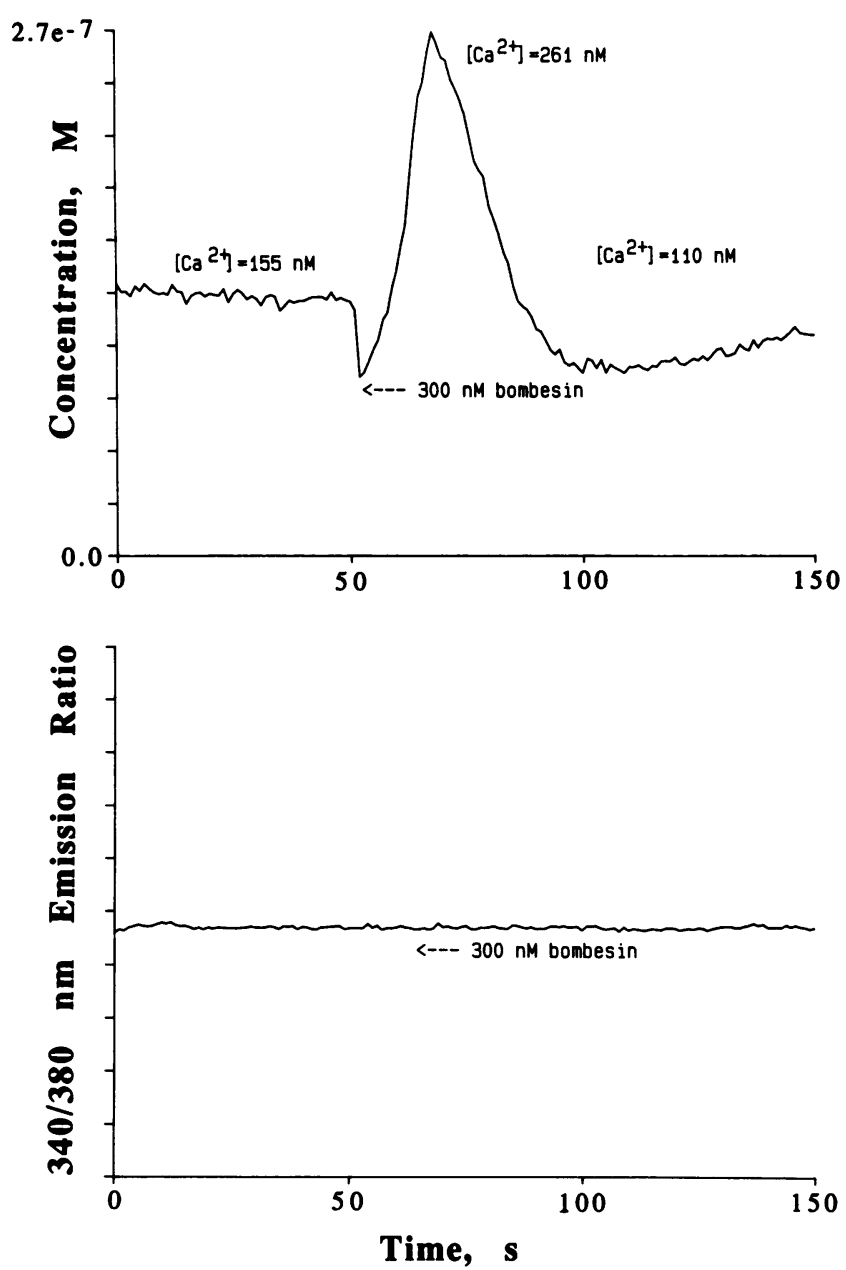

Figure 7. Elevation of $\left(\mathrm{Ca}^{2+}\right)_{\mathrm{i}}$ in response to bombesin. A typical example of the effect of bombesin on $\left(\mathrm{Ca}^{2+}\right)_{i}$ concentration are shown. Measurements were done in the absence (top) and in the presence (bottom) of $30 \mu \mathrm{M}$ bombesin-specific antagonist SC196.

erence 29). The mechanism by which signal transduction activators modulate DDP sensitivity appears to vary. In the case of activation of the protein kinase A pathway, the major effect is an increase in DDP uptake (27), whereas activation of the EGF receptor or PKC does not alter uptake $(15,16)$. Bombesin and TNF $\alpha$ were selected for study because they are possible endogenous activators of $\operatorname{PKC}(9,26)$. Like TPA they failed to enhance DDP uptake, produced no change in GSH content or apparent GST activity, and did not alter the number of intrastrand cross-links formed. It is unlikely that enhancement of DDP sensitivity is mediated by a decrease in metallothioneins since these are relatively stable proteins with cellular half-lives of many hours (15) whereas the sensitization response was observed by $2 \mathrm{~h}$. No information is yet available on the effect of either TPA or bombesin and TNF $\alpha$ on the ability of 2008 cells to remove DDP adducts from DNA, and the mechanism of the bombesin and TNF $\alpha$ effect on DDP sensitivity remains to be determined. It is also noteworthy that, like TPA (15) but unlike EGF (16), bombesin and TNF $\alpha$ were able to modulate DDP sensitivity in both the DDP-sensitive and -resistant variants of 2008. In the case of EGF, we have been able to show that ability to modulate DDP sensitivity is a function of both
EGF concentration and receptor number (16). However, sensitivity to bombesin and TNF $\alpha$ is largely determined at the postreceptor level $(6,7,30)$, and such a relationship may not pertain to either of these factors.

The second major finding to emerge from these studies was that both bombesin and TNF $\alpha$ are mitogenic for human ovarian carcinoma 2008 cells. Although TNF $\alpha$ is cytotoxic to many types of tumors in vitro and in vivo, against 2008 cells it produced an effect similar to that of bombesin in stimulating cloning efficiency, colony size, and growth rate. Although the number of cell-surface receptors for bombesin and TNF $\alpha$ were not determined, these data clearly indicate the existence of physiologically significant numbers of receptor types responsive to both factors.

A direct mitogenic effect of bombesin has been reported for several other cells types, including small cell carcinomas (4) and Swiss 3T3 fibroblasts. Swiss 3T3 cells exhibit large numbers of receptors for a variety of growth factors, including bombesin (31), and a mitogenic effect was observed using a bombesin concentration only $3 \%$ of that needed by the 2008 cells. A mitogenic response to TNF $\alpha$ was reported also for human astrocytoma cells (32); although receptor number was not quantitated, the concentration of TNF $\alpha$ at which the effect was observed was well within the concentration range needed to produce a response in 2008 cells.

It is of interest that the mitogenic effect of bombesin and TNF $\alpha$ was very prolonged. A 2-h exposure to either agent followed by washing of the cells was sufficient to commit the 2008 cells to a change in growth rate that was still apparent 24-48 h later, and a change in the size of colonies produced that was detectable $15 \mathrm{~d}$ later. We have reported this same sort of response with EGF, where a brief exposure was sufficient to commit the 2008 cells to an altered colony morphology that was still present 10-14 d later (16). We speculate that the effects of bombesin and TNF $\alpha$ on the growth of 2008 cells may be indirect, and that brief exposure to either may be initiating the production of an autocrine growth factor that either produces and maintains the alteration in cytokinetics or potentiates such effects of factors already present in the culture medium. It is important to emphasize that the ability of bombesin and TNF $\alpha$ to enhance DDP sensitivity may not be linked to their mitogenic effects; these may be entirely independent effects of receptor activation.

The concentration of bombesin causing mitogenesis in 2008 cells was substantially higher (maximum effect 4,000 $\mathrm{nM}$ ) than that required for mitogenesis in Swiss 3T3 (33) or human small cell lung carcinoma lines (34) cells, raising the question of whether bombesin was working via another receptor. However, the studies with Swiss 3T3 and nonsmall cell lung cancer cells lines used continuous exposure to bombesin or gastrin-releasing peptide, whereas the dose-response curve depicted in Fig. 3 was obtained using only a $2-h$ exposure. Moreover, the ability of the bombesin receptor-specific inhibitor SC196 to block the bombesin-induced increase in $\left(\mathrm{Ca}^{2+}\right)_{i}$ established that the 2008 cells do contain bona fide bombesin receptors but not that this receptor type is responsible for the mitogenic or sensitizing response. These cells may also contain neuromedian B receptors, and it is possible that both receptor types may contribute to the mitogenic or sensitizing responses or that bombesin is producing these responses indirectly via another growth factor that is less effective on 2008 than the 
other cell types. Because of the toxicity of SC196 to 2008 cells it has not been possible to establish that blockade of the bombesin receptors can inhibit the bombesin-induced increase in DDP sensitivity or proliferation rate.

Interest in TNF $\alpha$ as a potential regulator of DDP sensitivity and/or tumor growth in human ovarian carcinoma is heightened by reports that a significant fraction of these tumors appear to produce TNF (35) and that TNF treatment of several human ovarian carcinoma xenografts increases their local invasiveness (10). TNF $\alpha$ is currently being tested in the United States as a treatment for ovarian carcinoma. Both our results and those of other investigators $(10,35,36)$ suggest the need for caution and careful assessment of whether TNF $\alpha$ might be detrimental to such patients.

\section{Acknowledgments}

This work was supported by grants CA35309 from the National Institutes of Health; grants $\mathrm{CH}-368,377$, and 486 from the American Cancer Society; grants from Bristol-Myers Squibb; a grant from the Jikei University School of Medicine, Tokyo, Japan; grants from the Swiss Cancer League and the Swiss Science Foundation; and a grant from Finnish Academy. This work was conducted in part by the Clayton Foundation for Research, California Division. Drs. Jekunen and Howell are Clayton Foundation Investigators. Dr. Christen is a recipient of a Young Investigator Award and a Clinical Research Career Development Award from the American Society of Clinical Oncology.

\section{References}

1. Berridge, M. J., and R. F. Irvine. 1984. Inositol triphosphate, a novel second messenger in cellular signal transduction. Nature (Lond.). 312:315-321.

2. Anastasi, A., V. Erspamer, and M. Bucci. 1971. Isolation and structure of bombesin and alytesin: two analogous active peptides from the skin of the European amphibians Bombina and Alytes. Experientia (Basel). 27:166-167.

3. Rozengurt, E., and J. Sinnett-Smith. 1983. Bombesin stimulation of DNA synthesis and cell division in cultures of Swiss 3 T3 cells. Proc. Natl. Acad. Sci. USA. 80:2936-2940.

4. Weber, S., J. E. Zuckerman, D. G. Bostwick, K. G. Bensch, B. I. Sikic, and T. A. Raffin. 1985. Gastrin releasing peptide is a selective mitogen for small cell lung carcinoma in vitro. J. Clin. Invest. 75:306-309.

5. Swope, S. L., and A. Schonbrunn. 1988. The biophasic stimulation of insulin secretion by bombesin involves both cytosolic free calcium and protein kinase C. Biochem. J. 253:193-202.

6. Zachary, I., and E. Rozengurt. 1985. High-affinity receptors for peptides of the bombesin family in Swiss 3T3 cells. Proc. Natl. Acad. Sci. USA. 82:76167620 .

7. Erusalimsky, J. D., I. Friedberg, and E. Rozengurt. 1988. Bombesin, diacylglycerols, and phorbol esters rapidly stimulate the phospholylation of an $\mathbf{M}_{\mathbf{r}}$ $=80,000$ protein kinase C substrate in permiabilized 3T3 cells. J. Biol. Chem. 263:19188-19194.

8. Patel, K. V., and M. P. Schrey. 1990. Activation of inositol phospholipid signaling and $\mathrm{Ca}^{2+}$ efflux in human breast cancer cells by bombesin. Cancer Res. 50:235-239.

9. Beutler, B., and A. Cerami. 1987. Cachectin: More than tumor necrosis factor. N. Engl. J. Med. 316:379-385.

10. Malik, S. T. A., D. B. Griffin, W. Fiers, and F. R. Balkwill. 1989. Paradoxical effects of tumor necrosis factor in experimental ovarian cancer. Int. J. Cancer. 44:918-925.

11. Kim, C.-M., W.-S. Hong, J.-O. Lee, T.-W. Kang, Y.-W. Kim, J.-K. Song, T.-K. Yun, and C.-Y. Kim. 1989. Enhancement of cytotoxicity of cisplatin in vitro by recombinant human tumor necrosis factor and/or recombinant human interferon-a, -b and -g. Jpn. J. Cancer Res. 80:904-909.

12. Mutch, D. G., C. B. Powell, M.-S. Kao, and J. L. Collins. 1989. In vitro analysis of the anticancer potential of tumor necrosis factor in combination with cisplatin. Gynecol. Oncol. 34:328-333.

13. Das, A. K., P. J. Walther, N. J. Buckley, and S. H. M. Poulton. 1989.
Recombinant human tumor necrosis factor alone and with chemotherapeutic agents. Arch. Surg. 124:107-110.

14. Brenner, D. A., M. O'Hara, P. Angel, M. Chojkier, and M. Karin. 1989. Prolonged activation of jun and collagenase genes by tumor necrosis factor-a. Nature (Lond.). 337:661-663.

15. Isonishi, S., P. A. Andrews, and S. B. Howell. 1990. Increased sensitivity to cis-diamminedichloroplatinum(II) in human ovarian carcinoma cells in response to treatment with 12-O-tetradecanoylphorbol-13-acetate. J. Biol. Chem. 265:3623-3627.

16. Christen, R. D., D. K. Hom, D. C. Porter, P. A. Andrews, C. L. MacLeod, and S. B. Howell. 1990. Epidermal growth factor regulates the in vitro sensitivity of human ovarian carcinoma cells to cisplatin. J. Clin. Invest. 86:1632-1640.

17. Eastman, A. 1985. Interstrand cross-links and sequence specificity in the reaction of cis-dichloro (ethylene-diamin)platinum(II) with DNA. Biochemistry. 24:5027-5032.

18. Disaia, P. J., J. G. Sinkovics, F. N. Rutledge, and J. P. Smith. 1972. Cell-mediated immunity to human malignant cells. Am. J. Obstet. Gynecol. 114:979-989.

19. Andrews, P. A., M. P. Murphy, and S. B. Howell. 1985. Differential potentiation of alkylating agent cytotoxicity in human ovarian carcinoma cells by glutathione depletion. Cancer Res. 45:6250-6253.

20. Andrews, P. A., M. A. Shiefer, M. P. Murphy, and S. B. Howell. 1988. Enhanced potentiation of cisplatin cytotoxicity in human ovarian carcinoma cells by prolonged glutathione depletion. Chem. Biol. Interact. 65:51-58.

21. Bradford, M. M. 1976. A rapid and sensitive method for the quantitation of microgram quantities of protein using the principle of protein-dye binding. Anal. Biochem. 72:248-254.

22. Eastman, A. 1986. Revaluation of interaction of cis-dichloro(ethylenediamine)platinum (II) with DNA. Biochemistry. 25:3912-3915.

23. Grynkiewicz, G., M. Poenie, and R. Y. Tsien. 1985. A new generation of $\mathrm{Ca}^{2+}$ indicators with greatly improved fluorescence properties. J. Biol. Chem. 260:3440-3450.

24. Chan, D., D. Dienhart, J. Stewart, M. Tagawa, P. Jewett, E. Braunschweiger, and P. Bunn. 1989. Response of small cell lung cancer (SCLC) cell lines to gastrin releasing peptide (GRP) analogues. Proc. Am. Assoc. Cancer Res. $30: 81$.

25. Chou, T.-C., and P. Talalay. 1984. Quantitative analysis of dose-effect relationships: the combined effects of multiple drugs or enzyme inhibitors. $A d v$. Enzyme Regul. 22:27-54.

26. Minamino, N., K. Kangawa, and H. Matsuo. 1984. Neuromedin B is a major bombesin-like peptide in rat brain: regional distribution of neuromedin $B$ and neuromedin C in rat brain, pituitary and spinal cord. Biochem. Biophys. Res. Commun. 124:925-932.

27. Mann, S. C., P. A. Andrews, and S. B. Howell. 1990. Modulation of cis-diamminedichloroplatinum(II) accumulation and sensitivity by forskolin and 3-isobutyl-1-methylxanthine in sensitive and resistant human ovarian carcinoma cells. Int. J. Cancer. 48:866-872.

28. Andrews, P. A., J. A. Jones, N. M. Varki, and S. B. Howell. 1990. Rapid emergence of acquired cis-diamminedichloroplatinum(II) resistance in an vivo model of human ovarian carcinoma. Cancer Comm. 2:93-100.

29. Andrews, P. A., and Howell, S. B. 1990. Cellular pharmacology of cisplatin: perspectives on mechanisms of acquired resistance. Cancer Cells (Cold Spring Harbor) (Review). 2:35-42.

30. Schultze, S., S. Nottrott, K. Pfizenmaier, and M. Krunke. 1990. Tumor necrosis factor signal transduction; Cell-type-specific activation and translocation of protein kinase C. J. Immunol. 144:2604-2608.

31. Wakelam, M. J. O., S. A. Davies, M. D. Houslay, I. McKay, C. J. Marshall, and A. Hall. 1986. Normal $P^{21 N-r a s}$ couples bombesin and other growth factor receptors to inositol phosphate production. Nature (Lond.). 323:173-176.

32. Lachman, L. B., D. C. Brown, and C. A. Dinarello. 1987. Growth-promoting effect of recombinant interleukin 1 and tumor necrosis factor for a human astrocytoma cell line. J. Immunol. 138:2913-2916.

33. Zachary, I., and E. Rozengurt. 1985. High-affinity receptors for peptides of the bombesin family in Swiss 3T3 cells. Proc. Natl. Acad. Sci. USA. 82:76167620.

34. Carney, D. N., F. Cuttitta, T. W. Moody, and J. D. Minna. 1987. Selective stimulation of small cell lung cancer clonal growth by bombesin and gastrin-releasing peptide. Cancer Res. 47:821-825.

35. Naylor, M. S., S. T. A. Malik, G. W. Stamp, T. Jobling, and F. R. Balkwill. 1990. In situ detection of tumor necrosis factor in human ovarian cancer specimens. Eur. J. Cancer. 26:1027-30.

36. Malik, S. T. A., M. S. Naylor, N. East, A. Oliff, and F. R. Balkwill. 1990. Cells secreting tumour necrosis factor show enhanced metastasis in nude mice. Eur. J. Cancer. 26:1031-1034. 